\title{
Measured depth of subcutaneous tissue on posterolateral arm of omalizumab patients
}

\author{
Ryan Potts ${ }^{1}$, Laura Kim² ${ }^{2}$ Clark Eeuwes ${ }^{3}$, Arunmozhi Dominic ${ }^{3}$ Immaculate Nevis ${ }^{4}$, Harold L Kim ${ }^{3,4^{*}}$ \\ From Canadian Society of Allergy and Clinical Immunology Annual Scientific Meeting 2012 \\ Calgary, Canada. 11-14 October 2012
}

\section{Background}

Omalizumab is a humanized antibody utilized for patients with moderate/severe allergic asthma. There is an estimated risk of anaphylaxis to omalizumab in $0.1 \%$ of patients. Omalizumab should be received in the subcutaneous tissue of the mid-posterolateral upper arm. There may be an increased risk of anaphylaxis if injections are received intramuscularly (IM). In our clinic, omalizumab is given with $B D$ Eclipse $^{\mathrm{TM}}$ Needle, which is routinely provided with the drug and has needle length $16 \mathrm{~mm}$. If a patient has a skin to muscle depth (STMD) less than $16 \mathrm{~mm}$, there is a risk of omalizumab being injected IM.

\section{Methods}

We reviewed charts in an allergy clinic where an ultrasound of the left posterolateral arm was completed to measure STMD. Patients were divided into two groups based on their STMD ( $>16 \mathrm{~mm}$ and $\leq 16 \mathrm{~mm})$ and baseline characteristics were compared. We conducted multivariable linear regression with age, sex, BMI and race. The percentages of patients with STMD greater than $4 \mathrm{~mm}$, $6 \mathrm{~mm}, 8 \mathrm{~mm}, 10 \mathrm{~mm}$, and $12 \mathrm{~mm}$ were determined.

\section{Results}

Ultrasounds were completed on 40 patients receiving omalizumab. Three (7.5\%) patients examined had $>16 \mathrm{~mm}$ of STMD. Baseline characteristics were consistent between the groups except for BMI $(p<0.05)$. Sex and BMI correlated with STMD based on the linear regression analysis. Also, 35 (87.5\%) patients had $>4 \mathrm{~mm}$ STMD.

\section{Conclusion}

With provided omalizumab needles, the risk of anaphylaxis may be increased as the injections may be given IM.

\footnotetext{
* Correspondence: hlkimkw@gmail.com

${ }^{3}$ University of Western Ontario, London, Ontario, Canada

Full list of author information is available at the end of the article
}

By reducing the needle length to $4 \mathrm{~mm}$, the risk will likely be reduced.

\section{Author details}

${ }^{1}$ University of Waterloo, Waterloo, Ontario, Canada. ${ }^{2}$ McGill University, Montréal, Québec, Canada. ${ }^{3}$ University of Western Ontario, London, Ontario, Canada. ${ }^{4}$ McMaster University, Hamilton, Ontario, Canada.

Published: 2 November 2012

doi:10.1186/1710-1492-8-S1-A5

Cite this article as: Potts et al:: Measured depth of subcutaneous tissue on posterolateral arm of omalizumab patients. Allergy, Asthma \& Clinical Immunology 2012 8(Suppl 1):A5.

\section{Submit your next manuscript to BioMed Central and take full advantage of: \\ - Convenient online submission \\ - Thorough peer review \\ - No space constraints or color figure charges \\ - Immediate publication on acceptance \\ - Inclusion in PubMed, CAS, Scopus and Google Scholar \\ - Research which is freely available for redistribution

C Biomed Central

( 2012 Potts et al; licensee BioMed Central Ltd. This is an Open Access article distributed under the terms of the Creative Commons Attribution License (http://creativecommons.org/licenses/by/2.0), which permits unrestricted use, distribution, and reproduction in any medium, provided the original work is properly cited. 